\title{
Retained placenta of dairy cows associated with managemental factors in Rajshahi, Bangladesh
}

\author{
Md. Hemayatul Islam, Md. Jalal Uddin Sarder, Syed Sarwar Jahan, Moizur Rahman, Marefa zahan, \\ Md. Abdul Kader, and K. M. Mozaffor Hossain \\ Department of Animal Husbandry and Veterinary Science, \\ University of Rajshahi, Rajshahi-6205, Bangladesh \\ Corresponding author: Md. Hemayatul Islam, email: hislam.islam@gmail.com \\ Received: 03-07-2012, Accepted: 14-08-2012, Published online: 22-01-2013
}

How to cite this article: Islam Md. H, Sarder Md. JU, Jahan SS, Rahman M, Zahan M, Kader Md. A and Mozaffor Hossain KM (2013) Retained placenta of dairy cows associated with managemental factors in Rajshahi, Bangladesh, Vet. World 6(4): 180184, doi: 10.5455/vetworld.2013.180-184

\begin{abstract}
Aim: The incidence of retained placenta of dairy cows in relation to individual animal level and farm management factors such as farm type, farm size, housing system, floor type, feed quality, time of parturition, farming experience of farmer and delivery pattern of cows was determined.

Materials and Methods: A total 1205 parturated dairy cows conducted in nine upazilas and four Metro Thana of Rajshahi district during July 2010 to June 2011 for attainment of the result. Individual animal and farm management factors associated with retained placenta were recorded in a structured questionnaire through face-to-face farmer's interview and reviewing farm records. The raw data were compiled and statistical SPSS program to analyze to obtained result.

Results: The overall incidence of retained placenta was $13.4 \%$. The incidence was significantly higher in Local $\times$ Sahiwal genotype (4.6\%) and late delivery (longer gestation period) (80\%) than their counter groups $(p<0.05)$. The large farm (6.0\%) had higher incidence and had no significant effect than medium and individual household. Similarly animals housed in Tin shed building with poor ventilation facilities (6.6\%), animal housed in unscientific concrete floor (6.8\%), animals mostly grassed along with small amount of straw supplied (5.4\%) and a farmer had less than one year farming experience (5.3\%) had not significant statistically show higher incidence of retained placenta.
\end{abstract}

Conclusion: The local genotype; mini farm; supplied better feed quality; vast farming experience of farmer and normal delivery with eutocia had less chance of retained placenta of dairy cows.

Keywords: dairy cows, incidence, managemental factors, retained placenta

\section{Introduction}

Livestock is a crucial part in the economic and social fabric of Bangladesh. In the year the total livestock and poultry of our Country is about 41.63 and 278.80 million [1]. The urban and rural society of Bangladesh has long been enjoying the contribution of livestock and poultry for meeting the demand of nutrition, livelihood, customs and culture is an agricultural dependent country. Reproductive diseases are of great concern to dairy producers worldwide. The estimation of loss and effects of diseases on milk production, fertility and survival are of great importance to assess cost-benefits of diagnosis, treatments and prevention efforts [2]. The incidence of RP varies from 2 to $10 \%$ of foaling in mares [3] and 4.0-16.1\% in cow [4]. However, this incidence can be much higher in problem herds. Also, it increases during summer with increased parity, milk yield in the previous seasons and following birth of male fetus [5] and the breed where it may reach 54\% in heavy draught than in light-weight mares [6]. The incidence of retention of placenta in cattle ranged between $5.2 \%$ and $23.5 \%$ [7,8]. Its incidence can be as high as $12 \%$ even in normal delivery [9]. Shamsuddin et al. [10] recorded about $63 \%$ of the retained placenta in government dairy farm, Savar, Dhaka. Majeed [11] observed that the incidence of the RFM in the FriesianHolstein cattle was $9.2 \%$ and this incidence indicate the RFM in cattle is a significant feature necessitating further study to find the proper solution to this problems. Retained placenta is one of the problematic reproductive diseases in our country. A retained placenta usually causes the cow to have an increased time from calving to the conception of the next calf. It is not uncommon for a cow with a retained placenta to delay the next pregnancy for 2-6 months. Obviously, a two-month delay will mean a late calving date in the following year. A six-month delay may result in an open cow next year at pregnancy checking time. So the problem retained placenta loss of production that fail to meet our protein demand and ultimately affect the food security achievement.

The authors conducted the study for achieving the following objectives;

- Calculation of the over all incidence of retention of placenta of dairy cows in Bangladesh.

- Evaluation of the effects of breed dairy cows on incidence retention of placenta.

- Determination of the effect of farm type, farm 
Table-1. Genotype wise effect on retention of placenta of dairy cows

\begin{tabular}{|c|c|c|c|c|c|c|c|}
\hline \multirow[t]{2}{*}{ Placental condition } & \multicolumn{4}{|l|}{ Genotype } & \multirow[t]{2}{*}{ Total } & \multirow{2}{*}{$\begin{array}{l}\text { Chi-Square } \\
\text { calculated value }\end{array}$} & \multirow{2}{*}{$\begin{array}{l}\text { Chi-Square } \\
\text { tabulated value }\end{array}$} \\
\hline & $\mathbf{L}$ & $L \times S L$ & $\mathbf{L} \times \mathbf{F}$ & LXF×SL & & & \\
\hline $\begin{array}{l}\text { Retained } \\
\text { Normally Expelled } \\
\text { Total }\end{array}$ & $\begin{array}{l}33(2.7 \%) \\
439(36.4 \%) \\
472(39.2 \%)\end{array}$ & $\begin{array}{l}56(4.6 \%) \\
304(25.2 \%) \\
360(29.9 \%)\end{array}$ & $\begin{array}{l}43(3.6 \%) \\
175(25.2 \%) \\
218(18.1 \%)\end{array}$ & $\begin{array}{l}30(2.5 \%) \\
125(14.5 \%) \\
155(12.9 \%)\end{array}$ & $\begin{array}{l}162(13.4 \%) \\
1043(86.6 \%) \\
1205(100.0 \%)\end{array}$ & 30.311 & $7.815^{\star}$ \\
\hline
\end{tabular}

$\mathrm{L}=$ Local, $\mathrm{SL}=$ Sahiwal, $\mathrm{F}=$ Friesian; * = significant at $(\mathrm{P}>0.05)$ level.

size, housing system, floor type of dairy cows on prevalence of retained placenta.

- Observation of the effect of feed quality of dairy cows on risk of retention of placenta.

- Establishing a sustainable managemental practices that could reduce the reproductive diseases like retained placenta of cows.

\section{Materials and Methods}

Study area: Different genotype of 1205 late stage pregnant dairy cows (from heifer to $8^{\text {th }}$ parities an absolutely for dairy purpose) was considered as experimental materials for the present study. Extensive survey and data were collected from dairy farm of 9 upazila and 4 Metro Thana of Rajshahi. The name of 9 upazila viz. Poba, Godagari, Tanor, Mohonpur, Bagmara, Putia, Durgapur, Bagha and Charghat and 4 Metro Thana were Boalia, Rajpara, Motihar and Shamukhdum at Rajshahi district in Bangladesh during the period from July 2010 to June 2011 to evaluate the incidence of retained placenta.

Data collection: A questionnaire was prepared including information were name and address of farmer, genetic composition of breed, and management related factors such as farm type, farm size, housing system, floor type, feed quality, time of parturition, farming experience of farmer and delivery pattern for achievement of the study. The genetic composition of cows was identified by external characteristics and their ancestral register. Retained placenta (RP) measure by the definition is the failure to expel the fetal membranes within 12 to $24 \mathrm{hrs}$ after calving and failure of the maternal immune system to successfully in bovines [4] or within 3 hours after foaling in equines [3]. Such phenomenon is a common, albeit poorly effect on milk yield and subsequent reproductive efficiency [5].

Grouping of animals: Proper data collection the experimental animals were grouped as follows:

Four genotype of cows were classified as Local (n $=470)$, Sahiwal $\times$ Local $(n=360)$, Holstein Friesian $\times$ Local $(\mathrm{n}=220)$ and Friesian $\times$ Sahiwal $\times$ Local $(\mathrm{n}=$ 189). According to ownership, the farm were separated in private farm $(n=1025)$ and Government farm $(n=$ 180). Farmer farmed with the number of cows, it was divided into Individual farm; owner having 1-5 cows ( $\mathrm{n}$ =341), Mini farm; owner having 6-10 cows $(\mathrm{n}=347)$ and large size farm; those farm having $>10$ cows $(\mathrm{n}=$ 517). The cows were divided into following groups considering housing pattern: These were- (Straw and mud build): Walls of cattle sheds were built by mud and roofs were straw made indicated as poor $(\mathrm{n}=322)$, (Half building): Cattle sheds were built by fence and tin indicated as medium $(n=565)$ and (Tin shed): Cattle sheds were built by brick and tin indicated as well $(n=318)$.

The pattern of floor experimental individuals : Categories to poor condition: cows were kept in traditional floor $(\mathrm{n}=294)$, medium condition; cows were kept with little facilities of concrete floor and manger $(\mathrm{n}=547)$ and good condition; cows were kept in scientific concrete floor and manger $(n=364)$. Feed quality of these cows were divided into 3 groups such as-Poor or traditional feed supply (only grazing and little straw feeding), Average (cows were supplied some concentrate and straw) and better (cows were supplied balanced feed i.e, concentrate, vitamin and mineral mixture before calving and diet including green grass \& straw). On the basis of farming experience of farmer grouped into none i.e. farmer having less than one year farming experience $(n=509)$, little i.e. 1 to 5 years farming experience $(n=401)$ and Vast i.e. more than five years farming experience $(\mathrm{n}=$ 295). Again the studied cows were grouped on the basis of time of parturition such as- Early (Before length of gestation i.e. before than 273 days $)(n=41)$, Normal (Normal gestation length i.e 273-291 days) $(\mathrm{n}=1056)$ and Late (After length of gestation i.e. after 291days time for delivery) $(n=108)$. Finally the experimental animal categories into the delivery patern of cows e.g Yes: Present ( $\mathrm{n}=69$ ) means abnormal delivery (dystocia) and No: Absent $(\mathrm{n}=1136)$ means normal delivery (euticia).

Statistical analysis: The data were complied and statistical SPSS program [12] and Chi- Square test to compare the result.

\section{Results and Discussion}

The over all incidence of retained placenta was $13.4 \%$ and this incidence indicate the RFM in cows is a significant feature necessitating further study to find the proper solution to this problems. This finding was in agreement with that recorded by Islam et al, and Sarder et al. $[13,14]$ but Islam et al and lower than that reported by others researchers [15-18]. The low incidence of retention of placenta could be due to the area, breed and indiscrimination of data collection [10] hormonal imbalance [19] nutrition [19,20] and genital infection [17,21].

The genotype had significant effect $(P<0.05)$ and the highest prevalence in $(4.6 \%)$ Friesian $\times$ Sahiwal and the lowest $(2.5 \%)$ in Local $\times$ Sahiwal $\times$ Holstein there after $(3.6 \%)$ Local $\times$ Holstein Friesian and $(2.7 \%)$ 
doi: 10.5455/vetworld.2013.180-184

Table-2. The effects of farm size on the incidence of retained placenta of dairy cows

\begin{tabular}{llllllll}
\hline Placental condition & $\begin{array}{l}\text { Farm Size } \\
\text { Individual }\end{array}$ & Mini & Large & Total & $\begin{array}{l}\text { Chi-Square } \\
\text { calculated value }\end{array}$ & $\begin{array}{l}\text { Chi- Square } \\
\text { tabulated value }\end{array}$ & Remarks \\
\hline Retained & $50(4.1 \%)$ & $40(3.3 \%)$ & $72(6.0 \%)$ & $162(13.4 \%)$ & 1.634 & 5.991 & $N$ \\
Normally Expelled & $291(24.1 \%)$ & $307(25.5 \%)$ & $445(36.9 \%)$ & $1043(86.6 \%)$ & & \\
Total & $341(28.3 \%)$ & $347(28.3 \%)$ & $517(42.9 \%)$ & $1205(100 \%)$ & & \\
\hline
\end{tabular}

Table-3. The effects of manage mental factors like housing system, floor type and feed quality on the incidence of retained placenta of dairy cows

\begin{tabular}{|c|c|c|c|c|c|c|c|c|c|}
\hline \multirow{2}{*}{$\begin{array}{l}\text { Type of } \\
\text { Placenta }\end{array}$} & \multicolumn{3}{|c|}{ Housing system } & \multicolumn{3}{|l|}{ Floor Type } & \multicolumn{3}{|c|}{ Feed quality } \\
\hline & Poor & Medium & Well & Poor & Medium & Good & Poor & Average & Better \\
\hline Retained placenta & $38(3.2 \%)$ & $80(6.6 \%)$ & $44(3.7 \%)$ & $29(2.4 \%)$ & $82(6.8 \%)$ & $51(4.2 \%)$ & $65(5.4 \%)$ & $59(4.9 \%)$ & $38(3.2 \%)$ \\
\hline Normal expelled & $284(23.6 \%)$ & $485(40.2 \%)$ & $274(22.7 \%)$ & $265(22.0 \%)$ & $465(38.6 \%)$ & $313(26.0 \%)$ & $375(31.1 \%)$ & $386(32.0 \%)$ & $282(23.4 \%)$ \\
\hline Total & $322(26.7 \%)$ & $565(46.9 \%)$ & $318(26.4 \%)$ & $294(24.4 \%)$ & $547(45.4 \%)$ & $364(30.2 \%)$ & $440(36.5 \%)$ & $445(36.9 \%)$ & $320(26.6 \%)$ \\
\hline \multicolumn{2}{|c|}{ calculated Chi square } & 1.037 & & & 4.464 & & & 1.358 & \\
\hline \multicolumn{2}{|c|}{ tabulated Chi square $(P \leq 0.05)$} & 5.991 & & & 5.991 & & & 5.991 & \\
\hline \multicolumn{2}{|c|}{ Remarks } & NS & & & NS & & & NS & \\
\hline
\end{tabular}

* = significant at $(P>0.05)$ level and NS= Non significant at $(P>0.05)$ level.

Table-4. Effect of length of gestation on the incidence of retained placenta of dairy cows

\begin{tabular}{|c|c|c|c|c|c|c|}
\hline Placental condition & Early delivery & $\begin{array}{l}\text { Length of gestation } \\
\text { Normal delivery }\end{array}$ & Late delivery & Total & $\begin{array}{l}\text { Chi- Square } \\
\text { calculated value }\end{array}$ & $\begin{array}{l}\text { Chi- Square } \\
\text { tabulated }\end{array}$ \\
\hline $\begin{array}{l}\text { Retained } \\
\text { Normally Expelled } \\
\text { Total }\end{array}$ & $\begin{array}{l}54 \\
54 \\
108\end{array}$ & $\begin{array}{l}75 \\
981 \\
1056\end{array}$ & $\begin{array}{l}33 \\
08 \\
41\end{array}$ & $\begin{array}{l}162 \\
1043 \\
1205\end{array}$ & 318.895 & $5.991^{*}$ \\
\hline
\end{tabular}

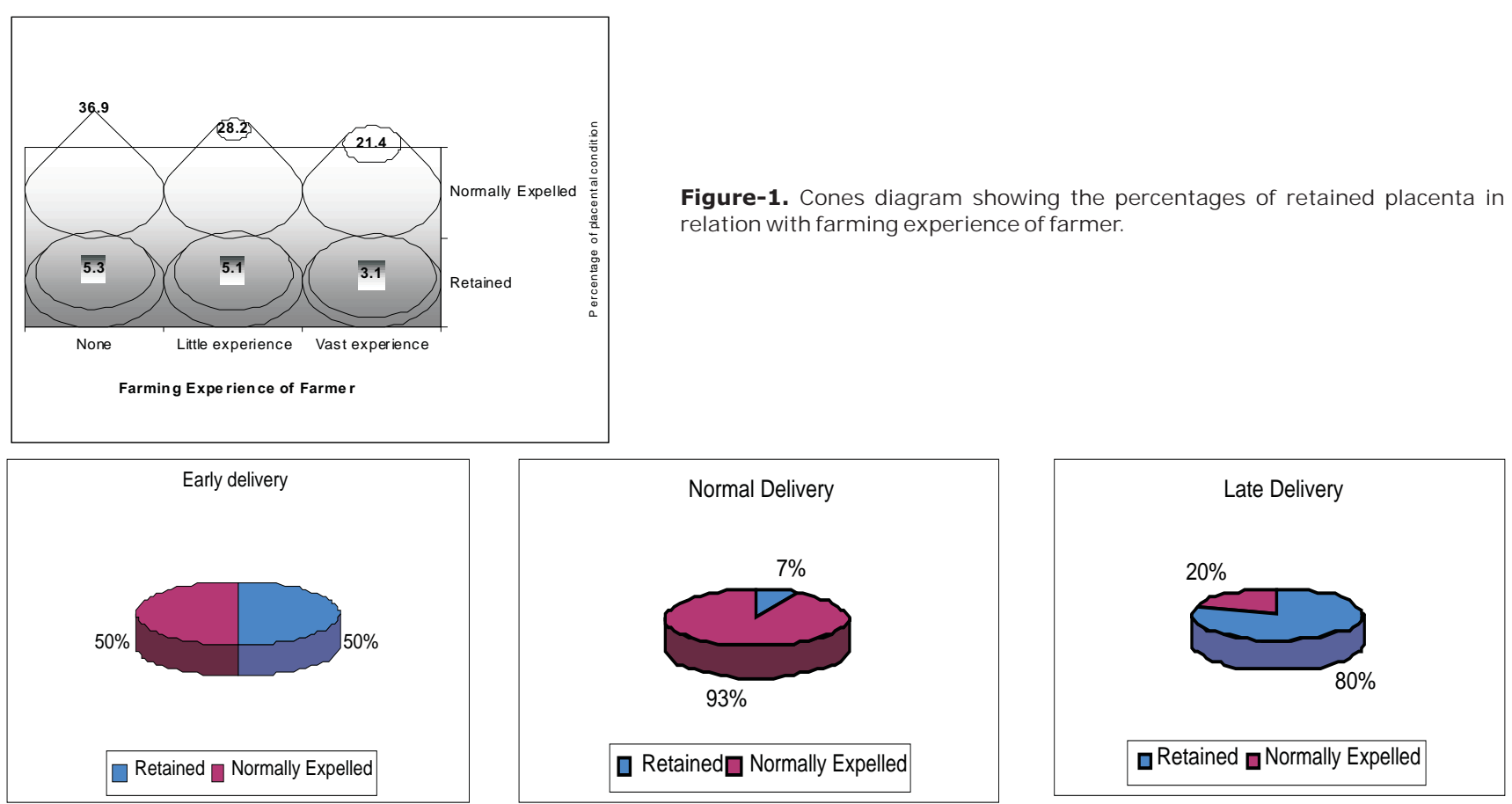

Figure-2. Pia diagram represent the percentages of retained placenta in relation with length of gestation of cows.

Local bred. Sarder et al. [14] showed 6.7\%, 13.2\% \& $13.4 \%$ of retained placenta in Local $\times$ Friesian, Local $\times$ Sahiwal \& Local $\times$ Sahiwal $\times$ Friesian cows which was little but different from the present study. Samad et al. [22] showed that Sahiwal and Friesian crosses had the lowest $(9.43 \%)$, where as local and Friesian crosses had the highest $(60.20 \%)$ incidence of placental retention followed by miscellan-eous group which had an incidence of $39.69 \%$ which was disagreement with the present study.

Farm size, farming experience and manage mental factors (like housing system, floor type and feed quality) had no significant effect $(\mathrm{P}>0.05)$ on retained placenta of dairy cows. The highest incidence of retained placenta was in large dairy farms $(6.8 \%)$, less than one year farming experience $(5.3 \%)$, medium house $(6.6 \%)$, medium floor $(6.8 \%)$ and poor quality feed $(5.4 \%)$ supplied than their correspondence group. Sarder [23] stated that retained placenta occurred more common in cows with poor housing system. Dryendahl et al. [24] reported similar results and mentioned that the risk of affection was rather greater during free than during the stall. Pavuna and Simunic [25] stated that there was no difference concerning the frequency of retention of placenta between the keeping animals in cows shed or free. Similarly, Grunert [15] reported that the incidence of retained placenta was related with nutritional imbalance. 


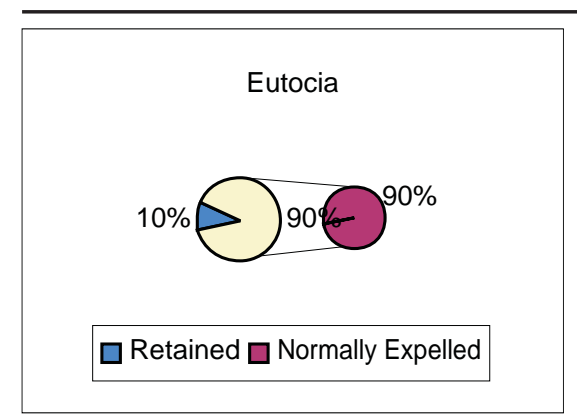

This study had significant effect $(P<0.05)$ on length of gestation and pattern of delivery on incidence of retained placenta. The highest incidence observer in prolong gestation period (80\%) and dystopia (68\%) related delivery. Samad et al. [22] reported $27.49 \%$ cases of retained placenta within normal gestation length (273-291days), 52.64\% in the abnormal gestation less than 273days and $38.0 \%$ in over time higher and more than 291 days. The frequency differs from each other and they indicated 3.3 days shorter for cows with retained placenta [16], 14\% incidence in early calved cows [26]. Many factors influence the retention of placenta including abortion, disease, dystocia, twin birth [27], nutrition and gestation length [24]. Erb and Morrison [24] reported that retention of placenta influenced by dystocia. Retention of placenta also influenced twining [28] caesarean section, fetotomy, abortion [15,29] and nutritional muscular dystrophy [15].

\section{Conclusions}

* The breed has genetic composition of Local $\times$ Sahiwal is more chance to retained placenta than local and other groups.

* Large farm, poor quality feed are prone to incidence of retained placenta.

* Prolong gestation period and dystocia has great opportunity for the incidence of retained placenta.

\section{Author's contribution}

It was the MS thesis experiment of first author. Other authors contributed equally. All authors read and approved the final manuscript.

\section{Acknowledgements}

The author acknowledge the Department of Animal Husbandry and Veterinary Science, University of Rajshahi, Bangladesh and the government Dairy improvement farm at Rajabarihat in Rajshahi, Bangladesh was help to provided data and competitions of the study.

\section{Competing interests}

Authors declare that they have no competing interest.

\section{References}

1. Anonymous (2011) Bangladesh Economic Review.

2. Bar D and Ezra E. (2005) Effects of common calving diseases on milk production in high yielding dairy cows. Israel Journal of Veterinary Medicine 60:106-111.

3. Taylor F, Brazil T and Hillyer, M. (2010) Diagnostic Techniques in Equine Medicine. Second Edition, Saunders Elseiver.
4. Mohamed, A. and Amer A. (2009) Hormonal and biochemical anomalies in dairy cows affected by retained fetal membranes.http://priory.com/vet/cow fetal membrane.htm

5. El-Malky, O., Youssef M., Abdel-Aziz N. and Abd ElSalaam, A. (2010) Postpartum Performance of Buffaloes Treated With Gnrh To Overcome The Impact of Placenta Retention. Journal American Science 2: 225-233.

6. Cuervo-Arango, J., LVM, S., CertVRep, M., John, R., Newcombe, B. and MRCV, S, (2009) The Effect of Manual Removal of Placenta Immediately after Foaling on Subsequent Fertility Parameters in the Mare. Journal Equine Veterinary Science, 29: 771-774.

7. Roberts SJ. (1986) Retention of placenta. In: Veterinary Obstetrics and Genital Diseases (Theriogenology), Woodstock, Vermont, USA. pp. 373-388.

8. Majeed AFMB and Qassim MY. (1989) Retained placenta inlocal breed cattle. Mesopotamia Journal of Agriculture 21: 97-104.

9. Dewan ML and Rahman MM. (1987) Studies on retention of placenta in Savar Dairy Cows. Bangladesh Veterinary Journal 21: 50-53.

10. Shamsuddin M, Alam MGS and Ahmed JU. (1988) Reproductive disorders of crossbred caws. Bangladesh Veterinary Journal, 22:21-28.

11. Majeed AF, Aboud QM, Hassan MS and Muhammad AY. (2009) Retained fetal membranes m Friesian-Hoistein cows and effect of some treatment methods. Iraqi Journal of Veterinary Sciences 23: 5-8.

12. SPSS/PC, Windows for version-10.0. Release on 27.10.199 (Microsoft Corp). Trends. SPSS Inc., Michigan Avenue. Chicago. IL.pp:19-182.

13. Islam MH, Sarder MJU, Rahman M, Kader MA and Islam MA. (2012) Incidence of Retained Placenta in Relation with Breed, Age, Parity and Body Condition Score of Dairy cows. International Journal of Natural Sciences 2(1): 15-20.

14. Sarder MJU, Moni MIZ and Aktar S. (2010) Prevalence of reproductive disorders of crossbred cows in the Rajshahi district of Bangladesh. SAARC Journal of Agriculture 8(2): 65-75.

15. Grunert E. (1986) Etiology and pathogenesis of bovine retained placenta. In: Current Therapy in Theriogenology. Edt. Morrow DA. $2^{\text {nd }}$ ed. $\mathrm{W}_{13}$ Saunders Co. Philadelphia, London, Toronto, Mexico city pp. 237-242.

16. Muller LD and Owens MJ. (1974) Factors associated with the incidence of retained placenta. Journal of Dairy Science 57: 721-728.

17. Francos G. (1974) Observation on the frequency of reproductive disorders in dairy herds in Israel. Deutsche Tieraziliche Wochenschrift 81:135-138.

18. Kaikini AS, Chikalikar GK and Dindorkar CV. (1983) Reproductive disorders in Holstein $\times$ Gir $\mathrm{F}_{1}$ crossbred cows. Indian Journal of Animal Science 53(5): 556-558.

19. Romaniuk J. (1978) Fertility indices in dairy cows retained placenta. Bulletin of the Veterinary Institute 22: 54-59.

20. Ishak MA, Larson LL, Owen FG, Lowry SR and Erickson ED. (1983) Effect of selenium, vitamins and ration on placental retention and performance of dairy cattle. Journal of Dairy Science 66: 99-106.

21. Arthur GH, Noakes DE and Pearson H. (1989) Retention of 
fetal membrane. in: Veterinary Reproduction and Obstetrics. 5th ed. Bailliere Tindall, London pp. 241-252.

22. Samad MA, Rahman MH and Islam TS. (1989) Factors associated with placental retention in Savar dairy cattle. Indian Journal of Dairy Science 4: 42.

23. Sarder MJU. (2008) Occurrence of reproductive disorders in crossbreed cows of Northern Bangladesh. $15^{\text {th }}$ International Congress on Biotechnology in Animal Reproduction Abstracts, Bangladesh Agricultural University, Mymensingh pp74.

24. Dryendahl L, Mattson J and Peherson B. (1977) Retained Placenta in cattle incidence, clinical data and effects on fertility. Journal of the American Veterinary Medical Association 24: 529-541.

25. Pavuna and Simunic (1968) The investigation on occurrence of retention of placenta of cows in dairy farms. Veterinary
Glasnevin 22:379-388.

26. Alacan E. (1974) Etiology and treatment of placental retention in the cow: Comparison of three methods. Veterinary Fakuttesi Dergesi 21:3-4.

27. Bendixen PH, Vilson B, and Ekesbo I (1987) Disease frequencies in dairy cows in Sweden. II. Retained Placenta. Preventative Veterinary Medicine 4:377-387.

28. Erb RE and Morrison RA. (1959) Effects of Twinning on reproductive efficiency in a Holstein-Friesian herd. Journal of Dairy Science 42: 512-519.

29. Alam MGS and Dobson H. (1986) Postpartum release of Prostaglandins $\mathrm{F}_{2}$ alpha $\left(\mathrm{PGF}_{2} \mathrm{a}\right)$ and the effect of oestradiol benzoate on the concentration of $\mathrm{PGF}_{2}$ a metabolite in postpartum and normal cyclic cows. Bangladesh Veterinary Journal 20: 73-81.

$* * * * * * * *$ 